\title{
ANALISIS KORELASI ANTARA KEBIASAAN MEMBACA DAN KEMAMPUAN MEMBACA PEMAHAMAN PADA SISWA KELAS IX SMP KEMALA BAYANGKARI MAKASSAR
}

\author{
Muhammad Yusuf Yunus', Andri Machmury²
}

\begin{abstract}
This study aims to describe whether or not there is a relationship between reading habits and reading comprehension ability in class IX students of SMP Kemala Bayangkari Makassar. This study is a descriptive study using correlational analysis methods. The population in this study was 200 students and the sample was 40 students. In this study data was collected from two sources, namely the questionnaire value from the results of the reading habit questionnaire test and the value of reading comprehension ability from the results of the comprehension reading ability test. Data obtained in the form of primary data using a quantitative descriptive approach with an objective process and analyzing data. The results of the analysis in this study indicate that the relationship between reading habits and reading comprehension ability of class IX students at SMP Kemala Bayangkari Makassar has a positive correlation. In this study, it is hoped that the readers and writers themselves will be able to further improve their reading skills.
\end{abstract}

Keywords: reading comprehension, reading habits, product moment correlation

\section{PENDAHULUAN}

Salah satu aspek keterampilan berbahasa yang sangat penting peranannya dalam upaya melahirkan generasi masa depan yang cerdas dan kreatif adalah keterampilan membaca. Kridalaksana (1984:122) mengemukakan bahwa membaca adalah menggali informasi dari teks, baik dari yang berupa tulisan maupun gambar, atau membaca adalah keterampilan mengenal,

*) Prodi Manajemen Bisnis Konvensi dan Perhelatan, Politeknik Pariwisata Makassar.

E-mail: yusuf.ogan@poltekparmakassar.ac.id 
memahami bahasa tulisan dalam bentuk urutan lambang-lambang grafis dan perubahannya menjadi wicara bermakna dalam bentuk pemahaman diam-diam atau pengujaran keras-keras. Ada yang hanya membaca tanpa memperhatikan tanda baca dan ada juga yang hanya membaca tanpa mengamati hal-hal penting yang hendak dibaca sehingga pembaca tidak memahami apa makna dari bacaan yang dibacanya. Hal itu terjadi karena teknik membacanya belum tepat atau karena faktor kebiasaan membaca sejak kecil lalu diterapkan sampai dewasa. Selain masalah tersebut, ada juga yang biasanya mendapat masalah lain, seperti kendala membaca pada saat proses membaca. Hal itu terjadi karena teknik membacanya belum tepat atau karena faktor kebiasaan membaca sejak kecil lalu diterapkan sampai dewasa.

Menurut Mulyati (1997: 490) langkah atau kegiatan membaca pemahaman, yaitu (1) Prabaca (Previewing), Prabaca bertujuan mendapatkan gambaran umum mengenai bahan bacaan yang akan dibaca; (2) Pendugaan (Predicting), Setelah selesai beraktivitas prabaca, sebaiknya kita menduga-duga isi bacaan yang akan dibaca; (3) Membuat Rangkuman, Saat Pemahaman daya ingat kita terhadap isi buku atau artikel semakin mantap apabila selesai membacanya kita tuliskan sebuah rangkuman mengenai isi buku tersebut. Pada umumnya, guru bahasa Indonesia cenderung menggunakan pendekatan yang konvensional dan miskin inovasi sehingga kegiatan pembelajaran keterampilan membaca berlangsung membosankan. Para siswa tidak diajak untuk belajar membaca dan memahami, tetapi cenderung diajak membaca. Artinya, apa yang disajikan oleh guru di kelas bukan bagaimana agar siswa dapat membaca sekaligus memahami apa yang telah dibaca. Jika kondisi pembelajaran semacam itu dibiarkan berlarut-larut, bukan tidak mungkin keterampilan membaca di kalangan siswa akan terus berada pada hasil yang rendah. Para siswa akan terusmenerus mengalami kesulitan dalam memahami bacaan sehingga siswa juga akan merasa kewalahan dalam mengekspresikan hasil pemahaman dari bacaannya.

Dalam konteks demikian, diperlukan pendekatan pembelajaran keterampilan membaca yang inovatif dan kreatif sehingga proses pembelajaran bisa berlangsung aktif, efektif, dan menyenangkan. Siswa tidak hanya diajak untuk belajar tentang membaca, tetapi juga diajak untuk dapat memahami bacaan dalam suasana yang dialogis, interaktif, menarik, dan menyenangkan. Dengan cara demikian, siswa tidak akan terpasung dalam suasana pembelajaran yang kaku dan membosankan. Pembelajaran keterampilan membaca pun menjadi sajian materi yang selalu dirindukan dan dinantikan oleh siswa. 


\section{Pengertian Membaca}

Pengertian membaca telah dikemukakan oleh para ahli bahasa. Batasan pengertian tersebut pada hakikatnya sama meskipun hanya pengungkapannya dalam bentuk kalimat yang berbeda. Kridalaksana (1984: 122) mengemukakan bahwa membaca adalah menggali informasi dari teks, baik dari yang berupa tulisan maupun gambar, atau membaca adalah keterampilan mengenal, memahami bahasa tulisan dalam bentuk urutan lambang-lambang grafis dan perubahannya menjadi wicara bermakna dalam bentuk pemahaman diam-diam atau pengujaran keras-keras. Berdasaarkan kedua batasan pengertian di atas, dapat disimpulkan bahwa membaca adalah suatu kegiatan yang melibatkan unsur fisik dan nonfisik yang bertujuan memahami semua informasi yang terdapat dalam bacaan untuk keperluan tertentu dalam mencapai suatu keberhasilan.

\section{Membaca Pemahaman}

Menurut Mulyati (1997: 490) langkah atau kegiatan membaca pemahaman seperti di bawah ini:

1. Prabaca (Previewing)

Prabaca bertujuan mendapatkan gambaran umum mengenai bahan bacaan yang akan dibaca. Oleh karena itu, kegiatan prabaca perlu dipahami dan diterapakan dalam kehidupan kita supaya dapat terbantu untuk memahami isi bacaan.

2. Pendugaan (Predicting)

Setelah selesai beraktivitas prabaca, sebaiknya kita menduga-duga isi bacaan yang akan dibaca. Misalnya ketika akan membaca "sejarah perkembangan bahasa Inodnesia", kita meduga-duga bahwa isi buku tersebut memuat inofrmasi mengenai sejarah perkembangan bahasa Indonesia.

3. Membuat Rangkuman

Saat Pemahaman daya ingat kita terhadap isi buku atau artikel semakin mantap apabila setelah selesai membacanya kita tuliskan sebuah rangkuman mengenai isi buku tersebut. Pada bagian akhir sebuah rangkuman akan lebih baik dituliskan pula pendapat atau komentar mengenai subjek yang akan dibahas dalam sebuah buku atau artikel.

\section{Tujuan Membaca}

Kesimpulan-kesimpulan yang telah dibuat oleh para ahli dari beberapa penelitian yang telah dilaksanakan menunjukkkan bahwa: 
1) Gerakan bola mata pada waktu membaca berubah kecepatannya sejalan dengantujuan membacanya.

2) Kemampuan seseorang dalam memahami bahan bacaan secara nyata dipengaruhi tujuan membacanya (tujuan yang jelas akan meningkatkan pemahaman bacaan, sedangkan tujuan yang kurang jelas akan meghambat pemahaman).

3) Tujuan membaca yang terumuskan secara jelas akan mempengaruhi pemerolehan pemahaman bacaan.

4) Seseorang yang mempunyai daya baca tinggi (baik), mampu memanfaatkan teknik membaca yang bervariasi sejalan dengan tujuan membaca yang akan dicapainya. (Downing dan Leong, 1982: 33,254-255)

Membaca juga memiliki tujuan untuk mencari serta memperoleh informasi, mancakup isi, memahami makna bacaan, makna arti (meaning) erat sekali berhubungan dengan maksud tujuan, atau intensif kata dalam membaca.

Nurhadi (1989: 14) berpendapat bahwa tujuan membaca ialah 1) Memahami secara detail dan menyeluruh isi buku; 2) Menangkap ide pokok atau gagasan utama secara tepat; 3) Mendapatkan informasi tenatang sesuatu: 4) Mengenali makna kata-kata; 5) Ingin menegetahui peristiwa penting yang terjadi di masyarakat sekitar; 6) Ingin memperoleh kenikmatan dari sebuah karya sastra; 7) Ingin mengetahui peristiwa penting yang terjadi di seluruh dunia; 8) Ingin mencarai merek barang yang cocok untuk dibeli; 9) Ingin memiliki kebenaran gagasan pengarang; 10) Ingin memperoleh informasi tentang lowongan pekerjaan; 11) Ingin mendapatkan keterangan tentang pendapat seseoarang (ahli) tentang definisi suatu istilah.

\section{Metode Mengembangkan Kecepatan Membaca}

Adapun metode yang pernah dikembangkan ialah 1) Metode Kosakata, Metode kosakata adalah metode yang mengembangan kecepatan membaca melalui pengembangan kosakata; 2) Metode Motivasi, Mengapa disebut metode motivasi? Aneh tampaknya. Akan tetapi, begitulah metode ini disebut orang. Pikiran yang mendasari lahirnya metode ini ialah semakin tertarik atau berminatnya seseorang pada jenis buku tertentu semakin tinggi kecepatan dan pemahaman seseorang; 3) Metode Bantuan Alat, Ketika seorang membaca (melihat baris-baris bacaan, gerak matanya dipercepat dengan bantuan alat yang berupa ujung pensil, ujung jari, atau alat penunjuk khusus dari kayu; 4) Metode Gerak Mata, Metode Gerak Mata ialah Ketika seorang membaca (melihat baris-baris bacaan, gerak matanya dipercepat dengan bantuan alat yang berupa ujung pensil, ujung jari, atau alat penunjuk khusus dari kayu. 


\section{METODE PENELITIAN}

Jenis penelitian ini adalah penelitian deskriftif dengan menggunakan metode analisis korelasional. Metode ini digunakan untuk membuktikan ada atau tidaknya hubungan masalah yang diteliti pada siswa kelas IX SMP Kemala Bayangkari Makassar. Dalam penelitian ini ada dua variabel yang di gunakan yaitu variabel Bebas, sebagai variabel bebasnya adalah kebiasaan membaca yang dilambangkan dengan huruf $\mathrm{X}$ dan variabel Terikat, sebagai variabel terikatnya adalah kemampuan membaca pemahaman yang dilambangkan dengan huruf Y pada siswa kelas IX SMP Kemala Bayangkari Makassar pada tahun ajaran 2010-2011 yang berjumlah 200 siswa dari 6 kelas. Jumlah sampel dalam penelitian ini adalah 40 siswa. Hal ini sesuai dengan pendapat yang dikemukakan oleh Arikunto (1998: 107) bahwa apabila subjek penelitian kurang dari 100 sebaiknya diambil semua, dan jika subjeknya banyak dapat diambil $10 \%-15 \%$ atau $20 \%-25 \%$ atau lebih pada kemampuan peneliti.

Dalam pengumpulan data, penulis mengumpulkan data dari dua sumber yakni data nilai angket kebiasaan membaca dari hasil pengisian angket, dan nilai kemapuan membaca pemahaman dari hasil tes kemampuan membaca pemahaman. Angket yang akan dibagikan berjumlah 10 pertanyaan kebiasaan membaca dengan pilihan A, B, C, D, atau E. Instrumen angket kebiasaan membaca digunakan nilai/ skor 2 sampai dengan 10, sedangkan tes kemampuan membaca pemahaman siswa dengan memberikan soal isian singkat dengan jumlah soal sepuluh. Dengan kriteria penilaian setiap jawaban yang benar diberi nilai/ skor 10 (sepuluh). Sebagai tindak lanjut dari teknik pengumpulan data adalah teknik analisis data yang dipergunakan untuk menganalisis data yang diperoleh. Hal ini disebabkan data yang diperoleh masih berupa alat mentah atau data kasar. Data kedua variabel yang telah diperoleh selanjutnya dianalisis dengan metode statistik populasi dengan rumus korelasi produk moment adalah sebagai berikut :

$$
\mathbf{r}_{\mathrm{xy}}=\frac{N \Sigma x y-(\Sigma x)(\Sigma y)}{\sqrt{\left(N \Sigma x^{2}-(\Sigma x)^{2}\right)\left(N \Sigma y^{2}-(\Sigma y)^{2}\right)}}
$$

Keterangan :

$$
\begin{array}{ll}
\mathbf{r}_{\mathrm{xy}} & =\text { Pearson }-\mathbf{r} . \\
\sum \mathrm{x} & =\text { Jumlah skor distribusi } \mathrm{x} . \\
\sum \mathrm{y} & =\text { Jumlah skor distribusi } \mathrm{y} . \\
\sum \mathrm{xy}=\text { Jumlah perkalian skor } \mathrm{x} \text { dan } \mathrm{y} . & \\
\mathbf{N} & =\text { Jumlah responden } \mathrm{x} \text { dan y yang mengisi kuesioner. } \\
\sum \mathrm{x}^{2} & =\text { Jumlah kuadrat skor yang distribusi } \mathrm{x} .
\end{array}
$$


$\sum \mathrm{y}^{2}=$ Jumlah kuadrat skor yang distribusi $\mathrm{y}$.

Hasil pengolahan data yang telah diperoleh akan diefesienkan taraf signifikan dengan menggunakan $r$ table pada tingkat taraf $5 \%$. Selanjutnya data tersebut akan diberi interpretasi diberikan interpretasi terhadap korelasi antara kebiasaan membaca dan kemampuan membaca pemahaman sesuai dengan pedoman Interpretasi Tehadap Koefisien Korelasi berikut:

Tabel 1. Pedoman Untuk Memberikan Interpretasi Tehadap Koefisien Korelasi

\begin{tabular}{|c|c|}
\hline Interval Koefisien & Tingkat Hubungan \\
\hline $0,00-0,199$ & Sangat Rendah \\
$0,20-0,399$ & Rendah \\
$0,40-0,599$ & Sedang \\
$0,60-0,799$ & Kuat \\
$0,80-1,000$ & Sangat Kuat \\
\hline
\end{tabular}

Sugiono (2002: 216)

\section{HASIL DAN PEMBAHASAN}

Hasil skor jawaban angket kebiasaan membaca (variable $\mathrm{x}$ ) yaitu 3,142 dan skor jawaban tes kemampuan membaca pemahaman 3,016. Setelah memperoleh skor data sampel penelitian, dapat diketahui bahwa rata-rata tingkat kebiasaan membaca siswa tergolong tinggi, dengan rata-rata skor 78,55. Begitu pula, dengan data kemampuan membaca pemahaman siswa tergolong tinggi dengan rata-rata skor 75,4. Data skor yang telah dikumpulkan dari hasil angket kebiasaan membaca dan hasil tes kemampuan membaca pemahaman kemudian diolah dengan menggunakan rumus korelasi product moment dengan $r$ hitung adalah 0,332 .

Pada $r$ table dengan taraf kesalahan tertentu yang ditetapkan pada taraf signifikan $5 \%$ dengan jumlah responden 40 , maka harga $r$ table $=0,312$. Ternyata harga $r$ hiitung lebih besar dari $r$ table, sehingga Ho ditolak dan $\mathrm{H} 1$ diterima. Dengan demikian ada hubungan positif antara kebiasaan membaca dan kemapuan membaca pemahaman pada siswa kelas IX SMP Kemala Bayangkari Makassar.

Berdasarkan kriteria tingkat koefisien korelasi di atas, nilai $\boldsymbol{r}$ hitung $=$ 0.332 berarti berada pada rentang nilai di antara $0,20-0,399$. Dapat dikatakan bahwa nilai-niilai kebiasaan membaca dan kemampuan membaca pemahaman siswa kelas IX SMP Kemala Bayangkari Makassar mempunyai tingkat korelasi yang rendah. Hal ini berarti semakin sering siswa untuk membiasakan diri membaca maka akan semakin baik pula kemapuan membaca pemahaman yang dimiliki. 


\section{SIMPULAN}

Berdasarkan penelitian yang dilakukan terhadap kebiasaan membaca dan kemampuan membaca pemahaman siswa kelas IX SMP Kemala Bayangkari Makassar, Penulis memberikan kesimpulan dari hasil penelitian statistik di atas, diketahui bahwa nilai $r$ hitung $=0,332$ lebih besar dari $r$ table $=0,312$ pada taraf signifikan 5\% sehingga Ho ditolak dan H1 diterima. Dengan demikian dapat disimpulkan ada hubungan positif antara kebiasaan membaca dan kemapuan membaca pemahaman pada siswa kelas IX SMP Kemala Bayangkari Makassar. Berdasarkan pedoman kriteria tingkat koefisien korelasi nilai $\boldsymbol{r}$ hitung $=0.332$ berarti berada pada rentang nilai di antara $0,20-0,399$ yang berarti bahwa nilainiilai kebiasaan membaca dan kemampuan membaca pemahaman siswa kelas IX SMP Kemala Bayangkari Makassar mempunyai tingkat korelasi yang rendah. Hal ini berarti semakin sering siswa untuk membiasakan diri membaca maka akan semakin baik pula kemapuan membaca pemahaman yang dimiliki.

\section{SARAN}

Berdasarkan hasil penelitian, dapat dikemukakan beberapa saran yang mudah-mudahan bermamfaatat bagi pembaca maupun bagi penulis. Penulis menyampaikan saran hendaknya siswa lebih menerapkan kebiasaan membaca yang tinggi agar kemampuan membaca pemahaman dapat dicapai, hendakanya guru lebih menerapkan kebiasaan membaca siswa dengan menambah jam wajib kunjung ke perpustakaan, pihak sekolah juga sebaiknya lebih memperhatikan keadaan lingkungan sekolah tersebut agar dapat mengetahui bagaimana keadaan lingkungan sekolah. Selain itu penulis juga menyarankan agar pihak sekolah melakukan pendekatan yang lebih inovatif agar tercipta suasana keharmonisan antara siswa dengan guru, dan hendaknya orang tua dapat memberikan contoh kepada anak dalam hal kebiasaan membaca agar dapat membentuk budaya baca.

\section{DAFTAR PUSTAKA}

Arikunto, Suharsimi. 1997. Prosedur Penelitian Suatu Pendekatan. Jakarta: Rineka Cipta.

Downing, john dan Che Kan Leong. 1982. Psychology of Reading. New York: Mc Millan Publishing Co, Inc.

Kridalaksana, Harimurti. 1984. Kamus Linguistik. Jakarta: Gramedia.

Mulyati, Yet. 1997. Membaca. Jakarta: Cipta Karya.

Nurhadi. 1989. Bagaimana Meningkatkan Kemampuan Membaca. Bandung: Sinar Baru Algensindo.

Sugiono. 2002. Statistika Untuk Penelitian. Bandung: Alfabeta. 